\title{
Lytic enzymes associated with defective prophages of Bacillus subtilis: sequencing and characterization of the region comprising the $\mathrm{N}$-acetylmuramoyl-L-alanine amidase gene of prophage PBSX
}

\author{
Pascal F. Longchamp, Catherine Mauël and Dimitri Karamata
}

Author for correspondence: Dimitri Karamata. Tel: +412132060 75. Fax: +41213206078.

Institut de Génétique et Biologie Microbiennes, Rue César-Roux 19, 1005 Lausanne, Switzerland

\begin{abstract}
Prophage induction in Bacillus subtilis strains 168, S31 and W23 is accompanied by synthesis of two endolysins. The synthesis of those of strain 168 , with molecular masses of 32 and $34 \mathrm{kDa}$, was shown to be controlled by the repressor of the defective phage PBSX. The $32 \mathrm{kDa}$ protein corresponds to an $\mathrm{N}$-acetylmuramoyl-L-alanine amidase, and plays the major role in PBSXmediated lysis. Its structural gene, xlyA, is the last in the PBSX late operon, whose four most distal open reading frames have been cloned and sequenced. Analysis of the nucleotide sequence suggests that the two open reading frames preceding $x / y A$, designated $x h / A$ and $x h / B$, encode polypeptides whose combined action could play the role of a holin. The open reading frame upstream of $x h I A$, designated $x e p A$, encodes an exoprotein. The phage amidase, although endowed with a signal peptide, is apparently, like $X e p$, exported by a holin-like mechanism which does not involve the cleavage of the signal peptide. The presence on the B. subtilis chromosome of other, similar, genes, and their possible widespread occurrence, is discussed.
\end{abstract} Keywords: prophage PBSX, Bacillus subtilis phage, $N$-acetylmuramoyl-L-alanine amidase,
endolysin, holin

\section{INTRODUCTION}

All known isolates of Bacillus subtilis and of related sporeforming bacilli, such as B. natto, B. licheniformis, B. pumilus and $B$. amyloliquefaciens, are lysogenic for morphologically similar defective bacteriophages, characterized by contractile tails with fibres (Ionesco $e t$ al., 1964; Tsutsumi $e t$ al., 1990; Huang \& Marmur, 1970; Steensma et al., 1978). Their treatment with inducing agents leads to phage development and cell lysis (Okamoto et al., 1968). The liberated phage particles kill susceptible hosts, while being apparently unable to infect and either lysogenize or give rise to a lytic cycle (Okamoto et al., 1968). Efforts to cure cells of these prophages have remained unsuccessful and inconclusive (Buxton, 1980; D. Karamata, unpublished), leaving open the possibility that a function essential to cell economy is under phage control. The

\footnotetext{
Abbreviations: $\mathrm{Cm}$, chloramphenicol; $\mathrm{MMC}$, mitomycin C; ND, nephelometric density; rbs, ribosome-binding site.

The GenBank accession number for the nucleotide sequence reported in this paper is L25924.
}

ubiquity of these prophages and their extensive morphological and physiological similarities are compatible with their having a common ancestor, possibly as ancient as that of the spore-forming Firmicuta.

The most studied of these phages are PBSX, harboured by B. subtilis 168 (Ionesco et al., 1964; Seaman et al., 1964), and, to a lesser extent, PBSZ and PBSY, found in strains W23 and S31 (Okamoto et al., 1968). The isolation and characterization of PBSX mutants (Siegel \& Marmur, 1969; Thurm \& Garro, 1975b), as well as studies of phage development (Thurm \& Garro, 1975a; Mauël \& Karamata, 1984), were followed, more recently, by the sequencing of parts of the prophage genome and the identification of an early and a late prophage operon (Wood et al., 1990a, b).

We report here the identification of PBSX-associated endolysins, and the sequencing of the prophage region consisting of four open reading frames (ORFs), which encode the $N$-acetylmuramoyl-L-alanine amidase, two components of a possible holin-like protein, and an exoprotein. Specific aspects of the phage amidase and the 
Table 1. Bacterial strains, phages and plasmids

\begin{tabular}{|c|c|c|}
\hline & Genotype or description & Origin \\
\hline \multicolumn{3}{|c|}{ Escherichia coli } \\
\hline$P_{2} 392$ & $\begin{array}{l}\mathrm{F}^{-} \text {bsdR } 514 \text { supE44 supF } 58 \\
\text { lac Y1 galK2 galT22 metB1 } \\
\text { trpR55P2 lysogen }\end{array}$ & Genofit (Geneva, Switzerland) \\
\hline $\mathrm{DH} 5$ & 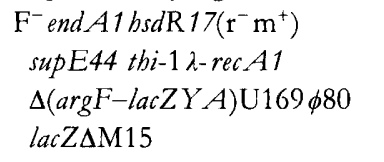 & Gibco BRL \\
\hline \multicolumn{3}{|c|}{ Bacillus subtilis } \\
\hline W23 & Prototroph, $\mathrm{Sm}^{\mathrm{R}}$ & Farmer \& Rothman (1965) \\
\hline S31 & Prototroph & Ionesco et al. (1964) \\
\hline \multicolumn{3}{|l|}{168 strains } \\
\hline 168 & $\operatorname{trp} C 2$ & Burkholder \& Giles (1947) \\
\hline L 4590 & $\operatorname{trp} C 2, P B S X:: p 517.5$ & This work; insertion of plasmid p517.5 in $168 \operatorname{trp} C 2$ \\
\hline QB 928 & aroI 906 purB33 dal-1 trpC2 & Dedonder et al. (1977) \\
\hline \multicolumn{3}{|l|}{ Phages } \\
\hline$\lambda C$ & Clone from PBSX prophage & Wood et al. (1990a) \\
\hline$\lambda 517$ & Clone from PBSX prophage & P. Longchamp, University of Lausanne \\
\hline \multicolumn{3}{|l|}{ Plasmids } \\
\hline pMTL20EC & $\mathrm{Ap}^{\mathrm{R}} \mathrm{Cm}^{\mathrm{R}} \mathrm{Em}^{\mathrm{R}}$ & Chambers et al. (1988) \\
\hline pMTL21 & $A p^{R}$ & Oultram et al. (1988) \\
\hline pWD1 & $\mathrm{Cm}^{\mathrm{R}}$ & H. Wood, Trinity College Dublin \\
\hline pLP1C & $A p^{R} C_{m}^{R}$ & $\begin{array}{l}1.1 \mathrm{kbp} \text { EcoRI fragment containing the } \mathrm{Cm}^{\mathrm{R}} \text { gene } \\
\text { from pWD1 in to the EcoRV site of pMTL21 }\end{array}$ \\
\hline pC2 & $A p^{R} \mathrm{Cm}^{R} \mathrm{Em}^{\mathrm{R}}$ & SacI-Sall fragment C2 (Fig. 2) in pMTL20EC \\
\hline p517.9 & $A p^{R} C^{R}$ & SacI-Bam HI fragment 517.9 (Fig. 2) in pLP1C \\
\hline p517.5 & $\mathrm{Ap}^{\mathrm{R}} \mathrm{Cm}^{\mathrm{R}}$ & SacI-PstI fragment 517.5 (Fig. 2) in pLP1C \\
\hline p517.1 & $\mathrm{Ap}^{\mathrm{R}} \mathrm{Cm}^{\mathrm{R}} \mathrm{Em}^{\mathrm{R}}$ & SacI-SphI fragment 517.1 (Fig. 2) in pMTL20EC \\
\hline p517.13 & $\mathrm{Ap}^{\mathrm{R}} \mathrm{Cm}^{\mathrm{R}} \mathrm{Em}^{\mathrm{R}}$ & SacI-SalI fragment 517.13 (Fig. 2) in pMTL20EC \\
\hline $\mathrm{p} 517.2$ & $\mathrm{Ap}^{\mathrm{R}} \mathrm{Cm}^{\mathrm{R}}$ & $S_{a c I-S a c I}$ fragment 517.2 (Fig. 2 ) in pLP1C \\
\hline p517.6 & $\mathrm{Ap}^{\mathrm{R}} \mathrm{Cm}^{\mathrm{R}}$ & Pstl-Pst I fragment 517.6 (Fig. 2) in pLP1C \\
\hline p517.8 & $\mathrm{Ap}^{\mathrm{R}} \mathrm{Cm}^{\mathrm{R}}$ & SacI-PstI fragment 517.8 (Fig. 2) in pLP1C \\
\hline
\end{tabular}

widespread occurrence of regions similar to that encompassing the amidase are discussed.

\section{METHODS}

Bacterial strains and plasmids. These are listed in Table 1. B. subtilis clones in $\lambda$ EMBL3 (Frischauf $e t$ al., 1983), $[\lambda$ C (Wood $e t$ al., 1990a) and $\lambda .517$ (P. F. Longchamp, unpublished; see Fig. 2)], were subcloned into vectors pMTL20EC (Chambers et al., 1988), pMTL21 (Oultram et al., 1988) or pLP1C (Table 1).

Media and growth conditions. B. subtilis strains were grown in SA, SAT or TS medium (Karamata \& Gross, 1970). When required, up to $20 \mu \mathrm{g}$ chloramphenicol $\mathrm{ml}^{-1}$ was added. Cultures, aerated by bubbling, were grown at $37^{\circ} \mathrm{C}$. The cell concentration was followed using an EEL nephelometer (Diffusion system, London, UK). A nephelometric density (ND) of 100 corresponds to $8 \times 10^{7}$ cells ml ${ }^{-1}$. E. coli DH5 was grown in L medium supplemented, when necessary, by $50 \mu \mathrm{g}$ ampicillin $\mathrm{ml}^{-1}$.

Transformation. Transformation of $B$. subtilis was performed according to Karamata \& Gross (1970), with linear bacterial or circular plasmid DNA (each $1 \mu \mathrm{g} \mathrm{ml}^{-\mathbf{1}}$ ). Competent cells were kept frozen (Cutting \& Vander Horn, 1990). Plasmids were introduced into E. coli $\mathrm{DH} 5$ by the procedure of Chung et al. (1989). Transformants containing an integrated plasmid with a $\mathrm{Cm}^{\mathrm{r}}$ marker were selected on LA plates supplemented with $5 \mu \mathrm{g}$ chloramphenicol $\mathrm{ml}^{-1}$. They were purified by successive transfer onto plates containing 10,15 and $20 \mu \mathrm{g}$ chloramphenicol $\mathrm{ml}^{-1}$.

DNA manipulations. Restriction endonucleases, T4 DNA ligase, T4 DNA polymerase, calf intestinal alkaline phosphatase and Klenow polymerase were obtained from Biofinex (Switzerland), and used according to the supplier's instructions. DNA fragments for subcloning or preparation of probes were recovered from agarose gels by centrifugation through siliconized glass wool (Heery et al., 1990). Plasmid DNA was isolated from $E$. coli by the boiling method followed by cetyltrimethylammonium bromide precipitation (Del Sal et al., 1988). Chromosomal minipreparations of $B$. subtilis DNA were obtained by phenol-extraction from lysozyme- and SDS-treated cells (Noirot et al., 1987). Minipreps of phage $\lambda$ DNA were obtained by the method of Grossberger (1987).

DNA sequencing. Sets of deleted derivatives of relevant subclones introduced into the pUC-related vectors pMTL20EC, 
pMTL21 and pLP1C (Chambers et al., 1988; Oultram et al., 1988; Table 1) were obtained using the double-strand Nested Deletion Kit (Pharmacia). DNA sequencing was performed on both strands by the dideoxy-chain termination method (Sanger et al., 1977) with the Sequenase version 2.0 kit (USB), according to the supplier's instructions. $5^{\prime}-\left[\alpha-{ }^{35} \mathrm{~S}\right]$ Deoxythioadenosinetriphosphate $\left(>1000 \mathrm{Ci} \mathrm{mmol}^{-1}, \quad>37 \mathrm{TBq} \mathrm{mmol}^{-1}\right)$ was obtained from Amersham. M13 primer $17 \operatorname{mer}(-20)$ and M13 reverse primer $16 \mathrm{mer}(-24)$ were supplied by Biofinex. Oligonucleotides were synthesized with an SM oligonucleotide synthesizer (Beckman). Sequencing gels were prepared using Sequagel-6 from National Diagnostics. The sequence was compiled and analysed by the University of Wisconsin Computer Group Software (Devereux et al., 1984).

Hybridization procedures. For Southern hybridization (Southern, 1975), size-fractionated DNA samples were transferred from agarose to Hybond-N nylon membranes (Amersham) by alkali blotting (Reed \& Mann, 1985). Probes were prepared either by the random priming labelling method (Feinberg \& Vogelstein, 1983) using $\left[\alpha_{-}^{32} \mathrm{P}\right] \mathrm{dNTP}$ $\left(3000 \mathrm{Ci} \mathrm{mmol}^{-1}\right)$ from Amersham or with the Dig-DNA labelling and detection kit from Boehringer Mannheim.

Preparation of crude lysates for SDSPAGE. An overnight culture was resuspended in SAT medium supplemented, when necessary, with $20 \mu \mathrm{g}$ chloramphenicol $\mathrm{ml}^{-1}$. At an ND of about 30 , the culture was induced by addition of mitomycin C [MMC; $2 \mu \mathrm{g} \mathrm{ml}^{-1}$ (final concn)]. After $12 \mathrm{~min}$, cells were harvested by filtration $(0.45 \mu \mathrm{m}$ membrane filter, Millipore), washed and resuspended in fresh SAT medium. Induction of the strain carrying an $x h i$ mutation (thermosensitive PBSX repressor) was achieved by $15 \mathrm{~min}$ incubation at $48^{\circ} \mathrm{C}$. At $50 \mathrm{~min}$ after either MMC addition or temperature shift (ND $=70$ ), a $0.4 \mathrm{ml}$ sample was withdrawn from the culture and added to $1 \mathrm{ml}$ of ice-cold $0.02 \mathrm{M} \mathrm{NaN}_{3}$, centrifuged, resuspended in $30 \mu \mathrm{l} 0.02 \mathrm{M} \mathrm{NaN}_{3}$, and incubated for $30 \mathrm{~min}$ at $37^{\circ} \mathrm{C}$. As stated in the Results, lysis occurred through the action of induced phage lytic enzymes or added lysozyme $\left(1 \mathrm{mg} \mathrm{ml}^{-1}\right)$. Upon lysis, $30 \mu \mathrm{l}$ of doublestrength sample buffer was added and the samples were analysed by SDS-PAGE. Non-induced control cultures, grown in parallel, were treated with lysozyme.

Pulse labelling of proteins in MMC-induced cultures. Labelling of proteins with ${ }^{14} \mathrm{C}$-amino acids was performed in TS medium, according to the protocol of Mauël \& Karamata (1984).

Preparation of cell walls. Cell walls were obtained according to Studer \& Karamata (1988). Cells, grown in SA medium at $37^{\circ} \mathrm{C}$ to an ND of 100 , were collected by centrifugation, washed with cold double-distilled water, disrupted by the French press (SLM Instruments), and centrifuged (15000 r.p.m. for $15 \mathrm{~min}$, Sorvall SS34-rotor). The pellet, deproteinized by boiling three times in $3 \%(\mathrm{w} / \mathrm{v})$ SDS, was washed three times in boiling water to remove the SDS. Walls thus obtained were resuspended in water, frozen and lyophilized. Cell walls used as substrate for the amidase assay (see below) were labelled by ${ }^{14} \mathrm{C}$-L-alanine incorporation into B. subtilis strain QB 928, essentially according to Margot et al. (1991).

Lytic enzyme activity in SDSPAGE under renaturing conditions. SDS-PAGE was performed essentially as described by Mauël \& Karamata (1984). Cell walls were incorporated at a concentration of $0.1 \%$ into $12 \%$ gels. Proteins separated by electrophoresis were renatured with $0.1 \%$ Triton X-100, $10 \mathrm{mM}$ $\mathrm{MgCl}_{2}$ and $25 \mathrm{mM}$ Tris $/ \mathrm{HCl}\left(\mathrm{pH} \mathrm{7.5)}\right.$ for $16 \mathrm{~h}$ at $37^{\circ} \mathrm{C}$ (Foster, 1992). Following clearing of the cell wall substrate, achieved by lytic activities, gels were fixed, stained with $0 \cdot 1 \%$ methylene blue, and photographed. Subsequently, they were stained with Coomassie blue and processed for autoradiography. HyperfilmMP (Amersham) was used; exposure time was 1-2 d.

$\mathbf{N}$-Acetylmuramoyl-L-alanine amidase assay. Crude extracts were prepared as described above. Fifty minutes after MMC induction, $4 \mathrm{ml}$ of the culture was withdrawn and passed through a French press. Disrupted cells were centrifuged (15000 r.p.m. for $15 \mathrm{~min}$, Sorvall SS34-rotor at $4{ }^{\circ} \mathrm{C}$ ). The supernatant was filtered $(0.45 \mu \mathrm{m}$ membrane filter, Millipore) and used as enzyme stock. For the reaction, $2.6 \mathrm{mg}$ of ${ }^{14} \mathrm{C}-\mathrm{L}-$ alanine-labelled cell walls, at a concentration of $1.1 \mathrm{mg} \mathrm{ml}^{-1}$, were added to $2.5 \mathrm{ml}$ crude extract and incubated at $37^{\circ} \mathrm{C}$. The lysis and the amidase assay were according to Margot et al. (1991).

\section{RESULTS}

\section{Lytic enzymes associated with the induction of defective prophages of Bacillus subtilis}

To determine the lytic activities which accompany prophage induction, cultures of $B$. subtilis strains 168 $(\mathrm{PBSX})^{+}, \mathrm{W} 23 \mathrm{PBSZ}^{+}$and S31 (PBSY) ${ }^{+}$, in early

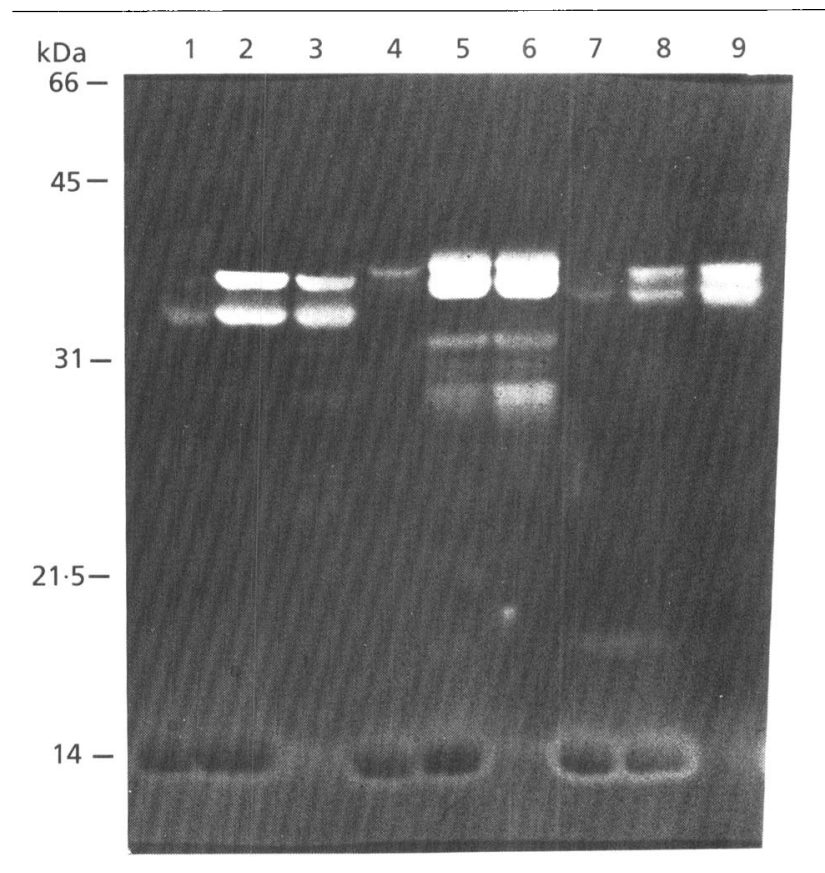

Fig. 1. Identification of lytic activities induced by $M M C$ treatment of $B$. subtilis strains S31, W23 and 168. Crude extracts from control and MMC-induced cultures were analysed by SDS electrophoresis on $12 \%$ polyacrylamide gels containing purified SDS-deproteinized B. subtilis 168 cell walls, as substrate for the lytic enzymes. Upon protein renaturation and staining with $0.1 \%$ methylene blue, clearing zones, corresponding to lytic enzyme bands, were identified. Samples were taken $50 \mathrm{~min}$ after removal of MMC. Control samples were from non-induced cultures at a comparable ND. Lysis conditions are specified below. The positions and molecular masses of protein standards, separated on the same gel, are indicated. Lanes 1, 4 and 7: non-induced cultures of strains S31, W23 and 168, respectively. Lanes 3, 6 and 9: MMC-induced cultures of strains S31, W23 and 168. Lanes 2, 5, and 8: MMC-induced and lysozyme-treated cultures of strains S31, W23 and 168, respectively. 


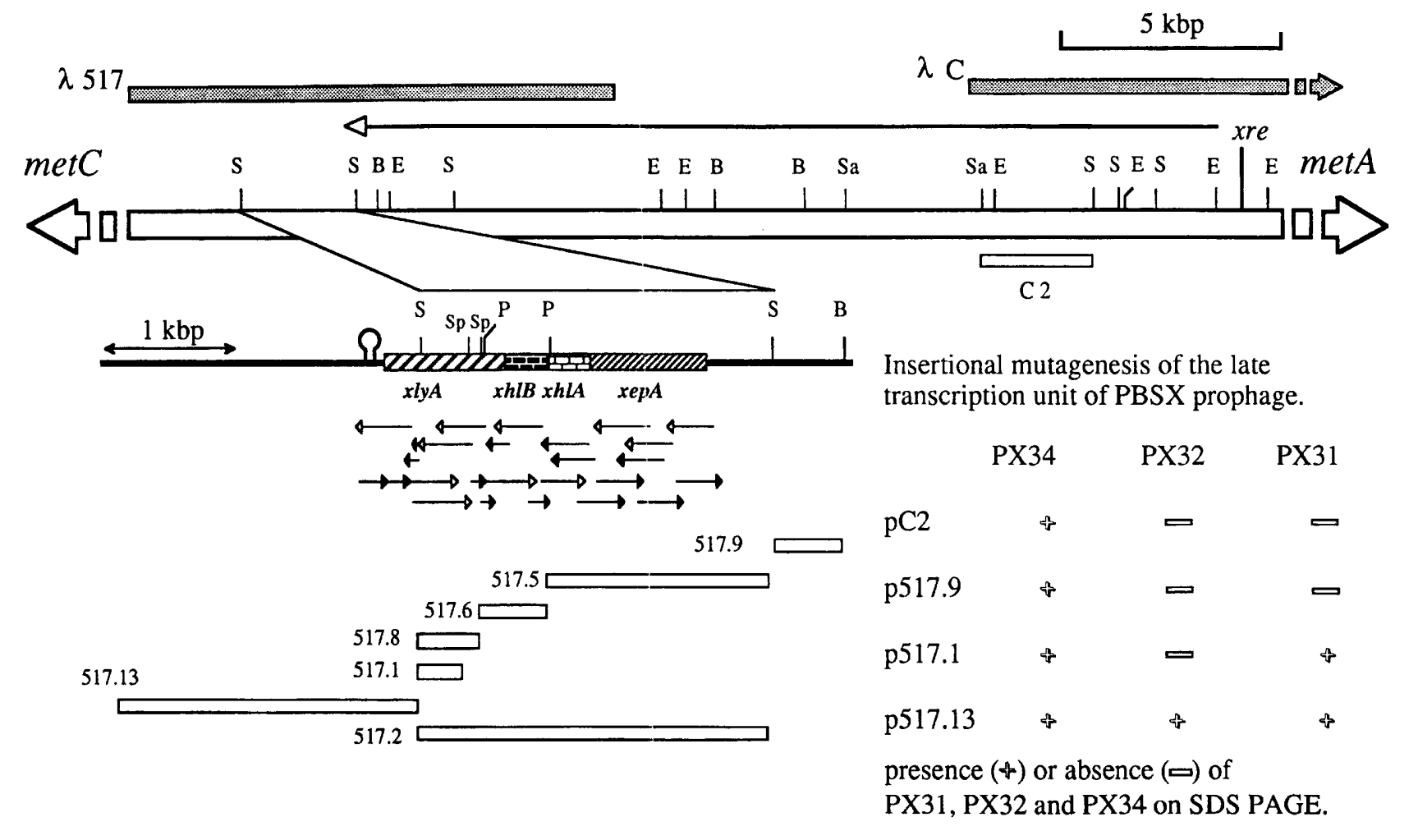

\begin{abstract}
Fig. 2. Physical map of the region encompassing $x l y A$, the structural gene of the PBSX $N$-acetylmuramoyl-L-alanine amidase. Relevant fragments of $\lambda$ clones 517 and $C$ were subcloned into integrational vectors pLP1C and pMTL20EC, and introduced by transformation into $B$. subtilis 168 . Selected $\mathrm{Cm}^{r}$ recombinants, carrying insertions of plasmids pC2, p517.9, p517.1 and p517.13 ( $\square$ ) were treated with MMC. Induced cells were radioactively labelled with a ${ }^{14} \mathrm{C}$-labelled amino acid cocktail, and separated on a $12 \%$ SDS gel containing deproteinized cell walls of $B$. subtilis 168 . The phage protein pattern (Fig. 3) and the lytic activities (Fig. 4) were analysed to determine the presence $(+)$ or absence $(-$ ) of PX34, PX32 and PX31. The map positions of PX32 (x/yA) and PX31 (xepA) are deduced from (i) the positions of the inserts, (ii) the presence or the absence of endolysin bands and those of other phage proteins and (iii) the known direction of transcription of the $18 \mathrm{~kb}$ PBSX late operon (Wood et al., 1990a). The position of $x r e$, the PBSX repressor gene, as well as that of the putative terminator $(\Omega)$ of the $18 \mathrm{~kb}$ transcription unit $(\checkmark-)$ are indicated. The nucleotide sequencing strategy of the chromosomal DNA region containing xlyA is also shown; the arrows indicate the origin, the extent, and the direction of sequence determination, as well as the nature of the primer used, i.e. M13 $(\longrightarrow)$ or synthetic $(\longrightarrow)$. Restriction sites are denoted: B, BamHI; E, EcoRI; Sa, Sall; S, Sacl; P, Pstl; Sp, Sphl.
\end{abstract}

exponential growth phase (ND $=30$ ), were treated for 12 min with $2 \mu \mathrm{g} \mathrm{MMC} \mathrm{ml}{ }^{-1}$, a treatment leading to the development of the defective phages (Mauël \& Karamata, 1984). At $50 \mathrm{~min}$, i.e. $10 \mathrm{~min}$ before the onset of lysis, $400 \mu \mathrm{l}$ samples were processed and analysed by electrophoresis on SDS-polyacrylamide gels containing native $B$. subtilis 168 cell walls (Leclerc \& Asselin, 1989; Foster, 1992). After renaturation of the proteins, each of the examined strains showed two bands associated with lytic activity (Fig. 1). The molecular masses of apparently analogous proteins were very similar: 32.5 and $33.5 \mathrm{kDa}$ (PX32 and 34) for strain 168 (Fig. 1, lane 9); 33 and $34 \mathrm{kDa}$ (PZ33 and 34) for W23 (Fig. 1, lane 6); and 32 and $33 \mathrm{kDa}$ (PY32 and 33) for S31 (Fig. 1, lane 3). The very weak bands corresponding to endolysins present in noninduced cultures were most likely due to spontaneous prophage induction (Fig. 1, lanes 1, 4 and 7). Treatment of MMC-induced cells with lysozyme did not significantly alter the profile of the autolytic activity on renatured gels (Fig. 1, lanes 8, 5 and 2 for 168, W23 and S31, respectively).
To assess if MMC-induced lytic enzymes are under the control of prophage regulatory elements, we used mutants deficient in $x r e$, the structural gene of the PBSX repressor (Wood et al., 1990b). Upon heat-induction, mutants bearing $x h i$, a mutation associated with a heat-labile repressor (Buxton, 1976), exhibited an endolysin SDSPAGE profile identical to that of MMC-induced strains, while mutation $x$ in associated with a repressor insensitive to MMC or UV induction (Thurm \& Garro, 1975b), prevented the appearance of the PX32 and PX34 bands in MMC-treated as well as in non-induced cultures (not shown). The latter observation confirmed that the low endolytic activity in non-induced cultures was due to spontaneous PBSX induction. Thus, the MMC-induced lytic enzymes of strain 168 are related to PBSX, suggesting, by analogy, that those of strains S31 and W23 are also likely to be under prophage control.

Occasionally, the main clearing zones were accompanied by additional, weak, lytic bands. However, the most frequently encountered ones were $x$ re-controlled. They 


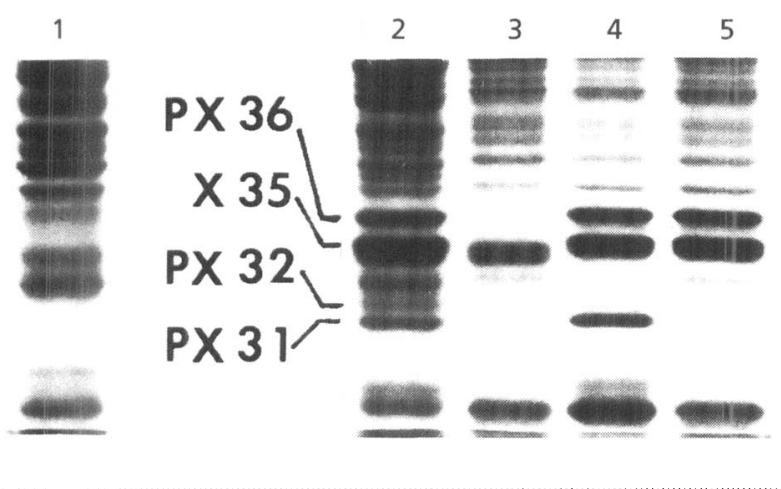

Fig. 3. Proteins synthesized during PBSX development. Samples were withdrawn $50 \mathrm{~min}$ after MMC induction, pulsed for $10 \mathrm{~min}$ with ${ }^{14} \mathrm{C}$-labelled amino acids and centrifuged. Upon lysis, enhanced by addition of lysozyme $\left(1 \mathrm{mg} \mathrm{ml}^{-1}\right)$, the pellets were subjected to electrophoresis on a $12 \%$ acrylamide gel and autoradiographed for $2 \mathrm{~d}$. The positions of previously identified proteins (Mauël \& Karamata, 1984) are indicated. Lane 1: $B$. subtilis 168, non-induced, control. Lanes 2, 3, 4 and 5: MMCinduced cultures of $B$. subtilis 168, and of strains carrying integrated plasmids pC2, p517.1 and p517.9 (see Fig. 2), respectively.

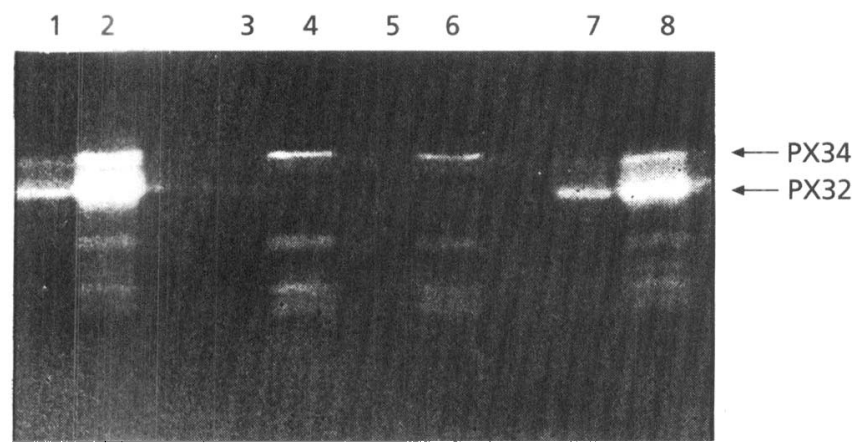

Fig. 4. Lytic activities associated with the induction of $B$. subtilis 168. Strains carrying an integrated plasmid were grown in the presence of chloramphenicol $\left(20 \mu \mathrm{g} \mathrm{ml}^{-1}\right)$. Samples $(0.4 \mathrm{ml})$, withdrawn $50 \mathrm{~min}$ after $\mathrm{MMC}$ induction, were processed for SDS-PAGE and loaded on a gel ( $12 \%$ polyacrylamide) containing vegetative $B$. subtilis 168 SDS-treated cell walls $(0.1 \%)$. Following electrophoresis, proteins were renaturated and the gel was stained with $0.1 \%$ methylene blue. Positions of relevant proteins are indicated. Lanes 1, 3, 5 and 7: untreated strains; 168 and strains carrying inserted plasmids pC2, p517.1 and p517.13, respectively. Lanes 2, 4, 6 and 8: MMC-induced strains; 168 and strains carrying inserted plasmids pC2, p517.1 and $\mathrm{p} 517.13$, respectively.

appeared as satellites to PX34 (not shown), corresponding most likely to degradation products of this rather labile protein (P. F. Longchamp, unpublished).

\section{Physical mapping of the genes encoding PBSX bacteriolysins}

To localize the structural genes of PX32 and PX34, the PBSX late transcription unit, shown to be responsible for phage-induced cell lysis (Wood et al., 1990a), was dis- rupted with integrational plasmids. Relevant inserts from $\lambda$ C (Wood et al., 1990a) and $\lambda 517$ were subcloned into the pUC derivatives pMTL20EC or pLP1C, yielding plasmids pC2, p517.9, p517.1 and p517.13 (Fig. 2). The latter were used to transform strain 168 with selection for $\mathrm{Cm}^{\mathrm{r}}$ recombinants. Integration occurred by recombination in the homologous PBSX prophage region, as confirmed by Southern hybridization (not shown). The $\mathrm{Cm}^{\mathrm{r}}$ recombinants carrying insertions were induced by MMC and examined for (i) cell lysis, (ii) the presence of PX32- and PX34-associated lytic activity (Figs 2 and 4), and (iii) the presence of proteins associated with PBSX induction (Mauël \& Karamata, 1984) (Fig. 3). In the latter experiments, MMC-induced cells were labelled with a ${ }^{14} \mathrm{C}$ labelled amino acid cocktail, and analysed by SDS-PAGE and autoradiography.

Insertion of pC2 (Fig. 3, lane 3) led to the disappearance of some of the virion's structural proteins, such as X35, and of those not incorporated into the mature phage particle, such as PX31, 32 and 36, previously denoted P31, 32 and 36, respectively (Mauël \& Karamata, 1984). Insertion of p517.1 led to the absence of PX32 only (Fig. 3 , lane 4). In both cases, the phage endolysin protein profile was characterized by the absence of PX32 and the presence of PX34 (Fig. 4, lanes 4 and 6). Inactivation of PX32 was associated with very poor lysis of the culture, compared to that obtained with 168 (PBSX) $^{+}$strains (Mauël \& Karamata, 1984). Insertion of the most distal clone, p517.13, had no effect on cell lysis and phage endolysin protein profile (Fig. 4, lane 8), suggesting that the relevant insert was either overlapping the extremity of the PX32 structural gene or was located downstream of it. Therefore, the latter gene was assigned to a $2 \mathrm{~kb}$ segment (Fig. 2), encompassing the left SacI site of the fragment inserted into p517.2. This conclusion is supported by the observation that E. coli DH5, carrying plasmid p517.2, undergoes spontaneous lysis during the stationary growth phase. None of the insertions affected the presence and the lytic activity of PX34, revealing that its structural gene is not located in the investigated PBSX late operon.

Insertion of p517.9 led to the absence of PX32 and PX31 (Fig. 3, lane 5), revealing that the structural gene of PX31, an exported protein (Mauël \& Karamata, 1984), is located, at least in part, between inserts 517.9 and 517.1, i.e. upstream of the structural gene of PX32.

\section{Nucleotide sequence of the PBSX genome region comprising xlyA, the gene encoding PX32}

The endolysin-encoding region, defined above, was sequenced on both strands according to the strategy outlined in Fig. 2. The sequenced segment (Fig. 5) contains four open reading frames. orf 4 , denoted $x l y A$ for PBSX lytic enzyme $A$ (see below), encodes a polypeptide of 297 amino acids with a molecular mass of $32 \mathrm{kDa}$. It is preceded by a ribosome-binding site (rbs) with an estimated free energy of $-13 \cdot 2 \mathrm{kcal}(-55 \cdot 23 \mathrm{~kJ}) \mathrm{mol}^{-1}$ (Shine \& Dalgarno, 1974; Tinoco et al., 1973), and followed by a potential terminator with an estimated free 


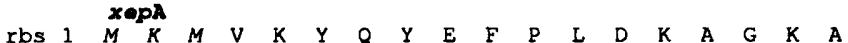

1 AGCCATGTAAGGCTTTTTTATTTTGCCTGTTTTTAGATCAAAGGAGGATGAAGATGGTGAAGTATCAATATGAATTTCCTCTCGATAAGGCTGGAAAAGC

$101 \underset{\text { CGGCGCTGTAAAGCCCTATCGAGGAGGAAAAAATGATTTTGTGACACCTGTTTCGAATTTGTCAGGCGTAGCGGAGATTTTAACAAATGCTGCTTTAAAG }}{\mathbf{G}}$

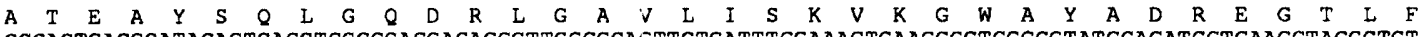

201 GCGACTGAGGCATACAGTCAGCTCGGGCAGGACAGGCTTGGCGCAGTTCTGATTTCGAAAGTGAAGGGCTGGGCGTATGCAGATCGTGAAGGTACGCTCT

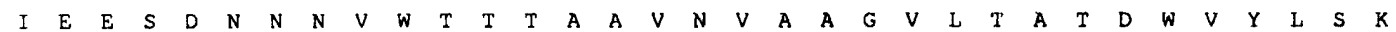

301 TTATAGAAGAAAGCGACAACAACAATGTTTGGACAACGACAGCAGCAGTTAATGTCGCAGCAGGCGTCCTGACAGCGACGGACTGGGTATATCTTTCTAA

$\begin{array}{lllllllllllllllllllllllllllllllllllll}R & Y & Y & R & F & R & Y & V & N & G & N & L & Q & Q & S & E & F & V & L & Y & Q & S & V & G & A & G & E & M & D & V & R & V & N\end{array}$

401 ACGCTATTACCGTTTCCGCTATGTGAACGGGAATCITCAGCAATC'TGAGTTTGTATTATACCAATCAGTCGGTGCGGGTGAGATGGATGTGCGTGTCAAT

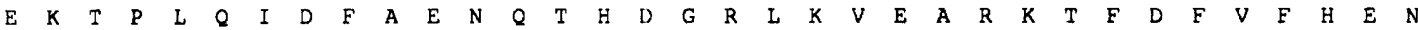

501 GAAAAAACGCCTTTACAGATTGACTTTGCGGAGAATCAAACACACGATGGACGGCTGAAAGTCGAGGCTCGCAAAACATTTGACTTTGTCTTTCATGAAA

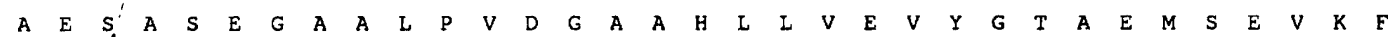

601 ATGCAGAGTCCGCCAGCGAGGGGGCTGCTTTACCTGTTGACGGTGCCGCGCATTTACTCGTTGAAGTCTACGGCACAGCAGAAATGAGCGAAGTCAAATT

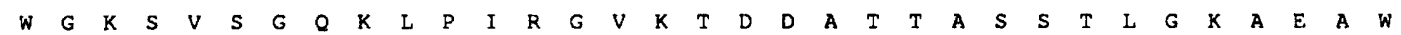

701 TTGGGGCAAATCGGTGTCAGGACAGAAACTGCCGATCAGAGGCGTGAAAACTGATGATGCTACCACTGCCTCCAGTACATTAGGAAAAGCTGAGGCATGG

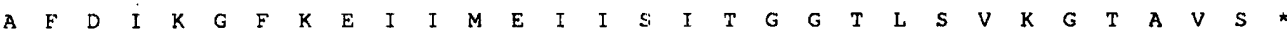

801 GCCTTTGATATTAAAGGGTTTAAGGAGATCATCATGGAGATTATCAGTATCACCGGCGGTACTCTTTCGGTAAAAGGGACCGCGGTTTCATAATAGTCTC

\section{rbs $2 \quad x h 1 A$}

901

GGCCCTCGGAAGGGAGGTGATCTGCATGTGAAGGAGGAGTGAGAGATGCAGCAAGAGGCAGACGTGAATGTGTTTCAGCAGGATTTAGCAGACATGAAAG

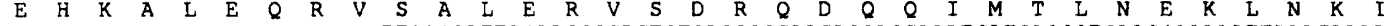

GCGAGCACAAAGCACTTGAGCAGAGGGTTTCCGCATT AGAACGCGI GTCTGACCGGCAAGACCAGCAAATCATGACGCTGAACGAAAAATTAAACAAAAT

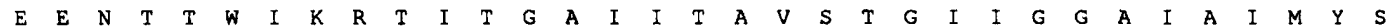

1101 TGAAGAAAACACCACGTGGATTAAACGCACCATCACAGGTGCCATCATTACAGCAGTGTCTACAGGCATCATTGGCGGAGCCATCGCCATTATGTACAGC

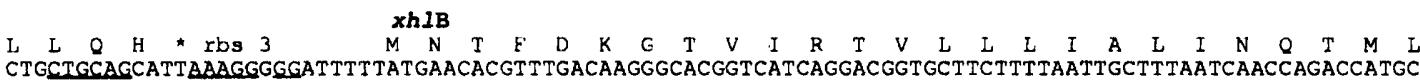
Pst I

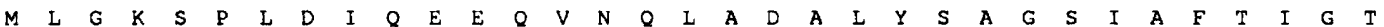

1301 TGATGCTCGGCAAATCACCATTGGACATTCAGGAGGAGCAGGTCAAICAGCTCGCTGACGCTCTTTATTCAGCCGGTTCCATCGCATTTACAATTGGAAC

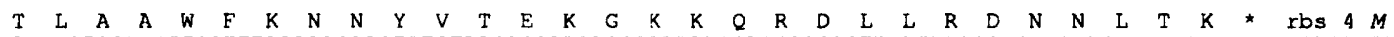

1401 GACACTTGCCGCTTGGTTTAAAAACAACTATGTAACAGAAAAAGgGAAAAACAGCGCGACTTGTTAAGGGACAATAATCTGACGAAATAAGGAGAGATG

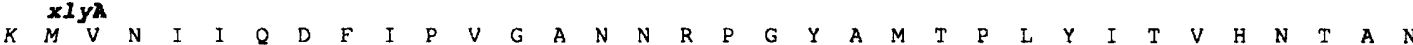
1501 AAAATGGTTAACATTATTCAAGACTTTATTCCGGTTGGCGCAAATAACCGTCCAGGCTACGCAATGACGCCGCTTTACATTACGGTGCACAACACAGCGA Hpa I

$\Downarrow$

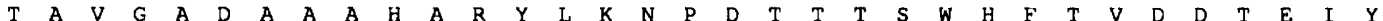
1601 ATACCGCAGTAGGAGCAGATGCTGCAGCGCATGCCCGCTATTTGAAAAATCCTGATACGACGACAAGCTGGCATTTTACAGTTGATGATACAGAAATTTA PstI SphI

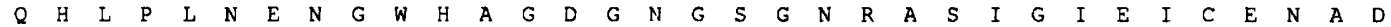

1701 TCAGCATCTGCCTTTAAATGAAAACGGCTGGCATGCGGGAGACGGAAATGGCAGCGGCAACCGGGCTTCTATTGGAATTGAAATTTGCGAAAATGCCGAT Sph I

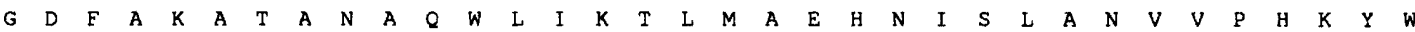

1801 GGCGATTTTGCAAAAGCAACAGCAAATGCCCAGTGGCTCATCAAAACATTAATGGCTGAACATAATATCAGTCTCGCCAATGTCGTCCCTCATAAGTAT'T

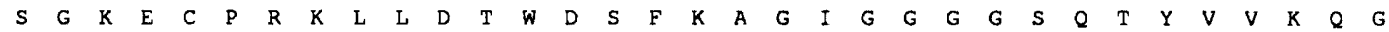

1901 GGTCAGGGAAGGAATGTCCGCGAAAATTGTTAGATACGTGGGATTCCTTCAAAGCAGGAATTGGGGGAGGCGGCAGCCAAACTTACGTCGTGAAACAGGG

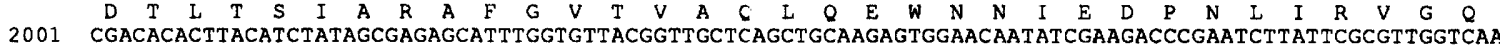

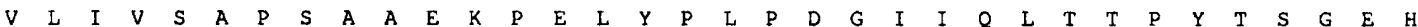
2101 GTATTAATTGTAAGTGCTCCATCGGCTGCTGAAAAACCCGAGCTCTATCCGCTCCCTGATGGTATCATTCAATTGACAACACCTTATACATCAGGAGAAC SacI

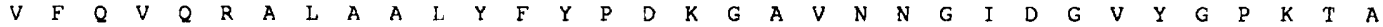

2201 ACGTCTTTCAGGTGCAACGAGCACTTGCGGCTCTGTATTTTTACCCTGATAAAGGCGCTGTTAACAACGGAATTGACGGCGTTTACGGACCGAAAACAGC

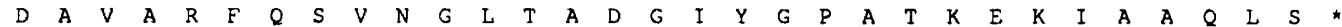

2301 TGACGCAGTTGCCCGTTTTCAGTCTGTTAACGGTCTAACTGCTGACGGTATCTACGGGCCTGCGACGAAAGAGAAGATCGCAGCGCAATTAAGCTGATCA $\gg \gg \gg \gg \gg \gg \gg>\quad<\ll<\ll<\ll<<<$

2401 AAGACCATAAAAATCCCGGAGCCGCTCCGGGATTTATTTTTTCTTCTTCAACTTTTTTATAATTCCAGCACTGCGCTCCCTCACCCGAAGCGAGTACCCG

Fig. 5. Nucleotide sequence of the region encompassing $x$ lyA, the structural gene of the PBSX N-acetylmuramoyl-Lalanine amidase. Putative ribosome binding sites (rbs) are underlined. The inverted repeat corresponding to a probable terminator is shown $(>>><<<$. The deduced amino acid sequence is given above the nucleotide sequence. Asterisks denote stop codons. The main restriction sites and the position of the potential cleavage site ( $\Downarrow$ ) of a putative leader sequence (von Heijne, 1986) are given. The dual translational signal MKM is indicated in italic. 
Table 2. Features of the $x e p A, x h / A, x h / B$ and $x / y A$ genes and their deduced products

\begin{tabular}{|c|c|c|c|c|}
\hline \multirow[t]{2}{*}{ Property } & \multicolumn{4}{|c|}{ PBSX } \\
\hline & $x e p A$ & $x h l A$ & $x h l B$ & $x l y A$ \\
\hline Size of (ORF (bp) & 843 & 267 & 261 & 891 \\
\hline Start codon & AUG & AUG & AUG & AUG \\
\hline Stop codon & UAA & UAA & UAA & UGA \\
\hline $\begin{array}{l}\Delta G \text { of } \mathrm{RBS}^{*}(\mathrm{~kJ} \\
\left.\mathrm{mol}^{-1}\right)\end{array}$ & -84.94 & $-75 \cdot 31$ & $-61 \cdot 1$ & $-55 \cdot 23$ \\
\hline $\mathrm{TA} / \mathrm{G}(:(\%)$ & $52 / 48$ & $52 / 48$ & $55 / 45$ & $53 / 47$ \\
\hline Length (amino acids) & 281 & 89 & 87 & 297 \\
\hline $\begin{array}{l}\text { Molecular mass } \\
(\mathrm{kDa})\end{array}$ & 31 & 10 & $9 \cdot 7$ & $31 \cdot 9$ \\
\hline Isoelectric point & 6.9 & $5 \cdot 1$ & $9 \cdot 9$ & $5 \cdot 6$ \\
\hline
\end{tabular}

* Calculated according to Tinoco et al. (1973).

energy of $-21 \mathrm{kcal}(-87 \cdot 86 \mathrm{~kJ}) \mathrm{mol}^{-1}$. The latter, which could form a stem-loop structure followed by a stretch of six thymine residues, probably ends the $18 \mathrm{~kb}$ transcription unit identified as the late phage operon (Wood et al., 1990a).

orf 1,2 and 3 encode polypeptides of 281,89 and 87 amino acids with molecular masses of 31,10 and $9 \cdot 7 \mathrm{kDa}$, respectively. They are preceded by putative rbs with estimated free energies of $-20 \cdot 3,-18$ and $-14.6 \mathrm{kcal}$ $(-84.94,-75.31$ and $-61.1 \mathrm{~kJ}) \mathrm{mol}^{-1}$, respectively. orf 1 encodes the previously identified exported protein PX31 and was accordingly designated $x e p A$ for PBS $X$ exported protein. orf 2 and orf 3 were denoted respectively $x h l A$ and $x b l B$ for PBS $X$ bolin-like protein (see below). The general properties of the four sequenced genes are summarized in Table 2.

The sequence of the PstI-Pst I fragment (bp 1204-1627), encompassing $x b l B$ and the beginning of $x l y A$, was previously reported by Lee $e t$ al. (1991). They showed that this fragment complemented the $\mathrm{Pho}^{-}$phenotype of $E$. coli pho. 4 strains under conditions inducing the expression of alkaline phosphatase. Therefore, they designated $x b l B$ as $x p a B$ for $X$ Phosphatase Activity. Our sequence (Fig. 5 ) and that of Lee et al. (1991) differ in the following points: GGCT instead of CGTG at bases 1555-1558; C instead of $G$ at base 1568; and, more significantly, CCGG instead of CCG at bases 1531-1534. The latter discrepancy, possibly due to a sequencing error, introduced an apparent frame-shift mutation which prevented Lee $e t$ $a l$. from identifying the beginning of the $x y l A$ gene.

\section{Deduced amino acid sequences of XlyA, XepA, XhIA and XhIB; search for homologies}

Computer analysis of the deduced amino acids sequence of XlyA revealed three domains with homologies to several polypeptides (Figs 6 and 10). The N-terminal region, encompassing amino acids 53-99, is highly similar to the $\mathrm{N}$-terminal region of $\mathrm{CwlA}$ (Kuroda \& Sekiguchi, 1990; Foster, 1991), a B. subtilis amidase, and to that of the Bacillus sp. hydrolase (Potvin et al., 1988) (Fig. 6a). It contains a consensus motif present in $\mathrm{N}$-acetylmuramoylL-alanine amidases (Lazarevic et al., 1992), as well as in several muramidases (Garcia et al., 1988, 1990). This motif is, however, absent from the B. licheniformis amidases, i.e. CwlL (Oda et al., 1993), and its highly similar gene orf $\mathrm{L} 3$ (Lee et al., 1991) (Fig. 6a: bold symbols). That the site of the amidase activity is confined to the $\mathrm{N}$-terminal region is in agreement with the observation that plasmid p517.2, containing $x l y A$ truncated at its $\mathrm{C}$-terminal (amino acids 216 to end), provokes lysis of E. coli DH5 in stationary phase. This conclusion is in line with the results establishing that the $\mathrm{C}$-terminal domain is not necessary for the activity of homologous proteins, CwlA (Kuroda \& Sekiguchi, 1990) and the Bacillus sp. hydrolase (Potvin et al., 1988). The C-terminal of proteins XlyA, CwlA and the product of the B. licheniformis orfL3 (Lee et al., 1991) is another region of high similarity (Figs $6 c$ and 10, amino acids 198 to end). No similarity was found with the Cterminal end of the Bacillus sp. hydrolase. The middle region (amino acids 148-220, Fig. 6b) is similar to several proteins involved in cell lysis: product of gene 15 of the $B$. subtilis bacteriophage $\phi 29$ (Garvey et al., 1986), Eh muram, the muramidase-2 from Enterococcus birae (Chu et al., 1992), and Sf cwhyd, the Streptococcus faecalis bacterial cell wall hydrolase (Beliveau et al., 1991). In addition, this region exhibits similarity to Ec dniR, a regulatory protein encoded by the dniR gene of E. coli (Kajie et al., 1991), and to $\mathrm{Sa}$ Prot A, the protein A of Stapbylococcus aureus Cowan1 (Shuttleworth et al., 1987). Finally, the comparison of the whole protein sequence revealed an identity of $44 \%$ between XlyA and CwlA, $38 \%$ between XlyA and OrfL3 of B. licheniformis, and $33 \%$ between XlyA and the Bacillus sp. hydrolase.

Protein XlyA has a typical export signal peptide with a potential cleavage site (von Heijne, 1986) located after the $\mathrm{Ala}_{40}$ residue (Fig. 5) and the dual translational start signal MKM (Fig. 5). Such a signal, also present in XepA, plays a role in the expression of gene $S$ of $\lambda$ (Young, 1992). Inspection of the $\mathrm{N}$-terminal amino acid sequence of XlyA (Foster, 1993) revealed that transcription begins at the second Met residue. Although no data are available for $x e p A$, the position of the putative rbs, overlapping the first $M$ codon, as in $x y A$, would suggest that its translation also starts at the second M codon.

The two small polypeptides, encoded by genes $x b l A$ and $x b l B$, located between $x e p A$ and $x l y A$, are highly similar to and have almost identical sizes to the $B$. licheniformis proteins encoded by genes orf $\mathrm{L} 1$ and orfL 2 located upstream of orfL3 (Lee et al., 1991). The identity between $x b l A, x b l B$ and orf L1, orfL2 is almost $63 \%$ (Figs 7 and $10)$. No such similarity was found within the region upstream of the B. subtilis cwl $A$ gene. However, the 100 amino acids encoded by the partially sequenced $\mathrm{C}$-terminal end of $\operatorname{orf} 1$, upstream of $\operatorname{cwl} A$, are highly similar $(58 \%$ identity) to the corresponding region of XepA (Figs 8 and $10)$. 
(a)

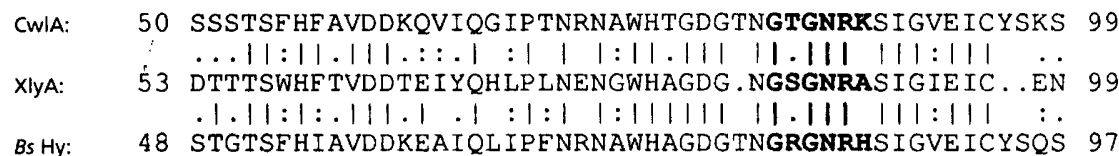

(b)

XlyA:

148 SFKAGIGGGGSQTYVVKQGDTLTSIAFAFGVTVAQLQEWN NIEDPNLIRVGQVLIVSAPSAAEKPELYPLPD

$.|||| 1.11 .11: \ldots|1||.:| .|| .1|:| 1|1| .: 1 .: .:$

$\phi 29$ gene 15:

149 VSRGTSSTKTTPKYKVKSGDNLTKIAKKHNTTVATLLKLNPS IKDPNMIRVGQTINVTGSGGK . . . . . .

$:|:::::||:||||:::|:::||:|:||||||||::|:|||| \mid::::$ | |:::

Eh muram:

284 GNSGGSATTTGTTYTVKSGDSVWG ISHSEG I TMAQL IEWNNI KN-NF I YPGQKLT I KGGQSAGSSTTNTGNNA

$:|::| 1|||||||::||::|||||:|::||:|:::|||||||| \mid: \quad::::$

Sf cwhyd:

596 GGSNNNQSGTNTYYTVKSGDTLNKI AA.QYGVTVANLRSWNG ISG-DL IFVGQKL IVKKGTSGNTGGSSNGGSN

$$
:|:::|||:|||:::||:||:|::::::|1:::||:|:||||:|: \quad:|::::
$$

Sa ProtA:

634 DGNKP GKED GNGVHVVKP GDTVND I AKANGTTADKIAADNKLADKNMI KP GQE LVVDKKQPANHADANKAQAL

(c)

CWIA: 171 SKASVAKKKTTNTSSKKTSYALPSGIFKVKSPMMRGEKVTQIQKALAAL.

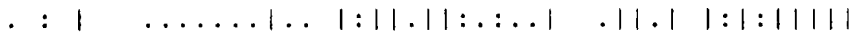

XIYA: 198 RVGQVLIVSAP SAAEKPELYPLPDGI IQLTTPYTSGEHVFQVQRALAAL . $::|::::|||:|::::||||| 1::::|:|:|1|:|1| 1 \mid 1$

OrfL: 580 STEKALSAAEASAAGKSKTWTLPDGIYKVKNP LMKGTAVTQIQTALAAL。 628

CWIA: 220 YFYPDKGAKNNGIDGVYGPKTADAIRREQSMYGLTQDGIYGPKTKAKLEA 269 |1|||||| $|1|||||||||||:|1||:| 1|| 1|||| \mid 1.1:$.

XlyA: 247 YFYPDKGAVNNGIDGVYGPKTADAVARFQSVNGLTADGIYGPATKEKIAA $|:|||||||||||||||||:|||||:| 1:|||||||| 1 \mid 1::$

OrfL3: $\quad 629$ YYYPDKGAKNNGIDGYYGMKTANAVKRFQLMYGLGADGIYGPKTKAKMLS 678

$\begin{array}{llll}\text { CWIA: } & 270 & \text { LLKX } & 272 \\ \text { XlyA: } & 297 & \text { QLSX } & 299 \\ \text { OrfL3: } & 679 & \text { LLKX } & 682\end{array}$

Fig. 6. Alignment of the $\mathrm{N}$-terminal (a), middle (b) and C-terminal (c) deduced amino acid sequence of XlyA with CwIA, an $N$-acetylmuramoyl-L-alanine amidase of $B$. subtilis (Kuroda \& Sekiguchi, 1990; Foster, 1991); Bs Hy, a Bacillus sp. cell wall hydrolase (Potvin et al., 1988); OrfL3, a protein of B. licheniformis (Lee et al., 1991); gene 15, the endolysin of bacteriophage $\phi 29$ (Garvey et al., 1986); Eh muram, the muramidase-2 from Enterococcus hirae (Chu et al., 1992); Sf cwhyd, the Streptococcus faecalis bacterial cell wall hydrolase (Beliveau et al., 1991); Ec dniR, encoded by the dni $R$ gene of E. coli (Kajie et al., 1991), and Sa Prot A, the gene encoding protein A from Staphylococcus aureus Cowan 1 (Shuttleworth et al., 1987). The consensus motif, endowed with an $\mathrm{N}$-acetylmuramoyl-L-alanine amidase, defined by Lazarevic et al. (1992), is in bold characters. Identical and similar amino acids are indicated by vertical lines and colons, respectively.

\section{PX32 encodes an $\mathbf{N}$-acetylmuramoyl-L-alanine amidase}

Preliminary results (Jaunin, 1987), suggesting that PX32 was an $N$-acetylmuramoyl-L-alanine amidase, were confirmed by the radioassay of Margot et al. (1991). The reaction mixture consisted of $1.1 \mathrm{mg} \mathrm{ml}^{-1}$ of cell wall labelled with ${ }^{14} \mathrm{C}$-L-alanine, to which was added $2.5 \mathrm{ml}$ samples of French-press-broken MMC-induced cells, collected $50 \mathrm{~min}$ after induction. Samples were withdraw'n at regular intervals and the increase of the free $\mathrm{L}^{-}$ $\left[{ }^{14} \mathrm{C}\right]$ alanine amino groups, generated by the amidase activity, was determined. Compared to the amidase activity of strain 168 , that of strain L4590::p517.5 was substantially reduced (Fig. 9), revealing that inactivation of $x l y A$ was associated with diminished amidase activity in the extract of the phage lysate. The residual amidase activity was likely to be due to the host enzyme LytC (CwlB) (Kuroda \& Sekiguchi, 1991; Lazarevic et al., 1992), poorly solubilized during the preparation of the 
(a)

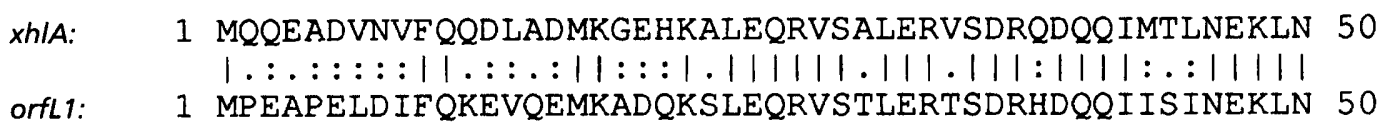

xhIA: $\quad 51$ KIEENTTWIKRTITGAITAVSTGIIAEPSPL 82

||||||||||$.|1|||||||||||::::$ :

orfl1: $\quad 51$ KIEENTTWIKRSITGAIITAVSTGIIGGAIAV 82

(b)

xh/B: 1 MNTFDKGTVIRTVLLLIALINQTMLMLGKSPLDIQEEQVNQLADALYSAG 50

|. $:|||||:|||||:|||:|||::|:||\ldots| \ldots:$ | $:|::|||||||||$

orfL2: $\quad 1$ MKHIDKGTVVRTVLLFIALVNQTLIMFGKPVLPVAEDQIHTLADALYSAG 50

xh/B: $\quad 51$ SIAFTIGTTLAAWEKNNYVTEKGKKQRDLLRDNNLTK 87

|||| $1: \ldots|| 1:.|1||| 1.1|1.1::: 1 \ldots 1| 1$

orfL2: $\quad 51$ SAAFTIAASLVAWYKNNYVTSKGKMQKEVLQKKGLTK 87

Fig. 7. Alignment of the deduced amino acid sequences of the $x h / A$ and $x h / B$ products with those of orfL1 (a) and orf $L 2$ (b) from B. licheniformis (Lee et al., 1991). Identical and similar amino acids are shown by vertical lines and colons, respectively.

\begin{tabular}{|c|c|c|c|}
\hline \multirow[t]{2}{*}{ xepA: } & 175 & \multicolumn{2}{|l|}{ RKTFDFVFHENAESASEGAALPVDGAAHLLVEVYGTAEMSEVKEWGKSVSGQKLP } \\
\hline & & ||$:|:|||:::|::||::::|:: \quad||:|||||||||:||||||:||| \mid$ & \\
\hline orf1: & $\mathrm{x} \times \mathrm{x}$ & SKTMD IVEHDKTET IGEGNPETVGSFKTLL IEVYGTAETSELKFWGKSLSGTKR & \\
\hline херА: & 230 & EI IME I ISITGGTLSVKGTAVS & \\
\hline & & $:|1|:|1: 1 \quad|:|1| 1|:|$ & \\
\hline orf1: & $\mathbf{x}$ & LRGQKVDDGTFATSTKGKSEAWSFSITGFKE IVMELTALTNGNF SVRGTAVS & \\
\hline
\end{tabular}

Fig. 8. Alignment of the deduced amino acid sequence of the xepA product with that of the partly sequenced orf1 from the $B$. subtilis CWIA region. Identical and similar amino acids are shown by vertical lines and colons, respectively.

crude extract, rather than to CwlA (Kuroda \& Sekiguchi, 1990 ; Foster, 1992), an amidase not induced by MMC treatment (Foster, 1993). Finally, since lysis of MMCinduced cells of strain L4590::p517.5 is very poor (not presented), it follows that PX32 is the main phage endolysin responsible for the degradation of the host cell wall.

\section{DISCUSSION}

The late operon of the $B$. subtilis bacteriophage PBSX (Wood et al., 1990a), like that of other similar bacteriophages, contains genes involved in phage morphogenesis, as well as those responsible for host lysis. The latter PBSX genes were localized at the distal end of this transcription unit (Fig. 10). In this respect, PBSX resembles $\phi 29$, a virulent $B$. subtilis phage (Garvey et al., 1986), but differs from coliphages $\lambda, \mu$, T4 and P1, where analogous genes occupy the proximal end of the late operon (Calendard, 1988). In both $\lambda$ and $\phi 29$, the unit responsible for cell lysis encodes two proteins, a so-called holin and an endolysin.
Their structural genes are $S$ and $R$ for $\lambda$, and $g 14$ and 15 for $\phi 29$ (Steiner et al., 1993), respectively. The holin is transcribed before the endolysin, a lytic transglycosylase for $\lambda$ and a murein hydrolase for $\phi 29$.

The four PBSX ORFs possibly involved in host lysis were localized between the gene encoding PX76 (Longchamp, 1990), the tail fibre protein, and the terminator of the late operon (Fig. 10). The most distal ORF, $x l y A$, was shown to encode an $N$-acetylmuramoyl-L-alanine amidase, which corresponds to the previously described protein P32 (Mauël \& Karamata, 1984). The enzyme, with an isoelectric point of $5 \cdot 6$, has a strong affinity for teichoic-acidcontaining walls (Mauël, 1984), and was shown to play the main role in the degradation of host cell wall.

The $x l y A$ gene is preceded by two small ORFs designated $x h l A$ and $x h l B$, each of which resembles a different part of the holins so far described (Young, 1992). Indeed, $x h / B$ encodes a protein of $9.7 \mathrm{kDa}$, which, like the $\lambda$ holin (gene $S$ ), possesses (i) two hydrophobic domains, separated by a short hydrophilic domain containing a reverse-turn Pro 


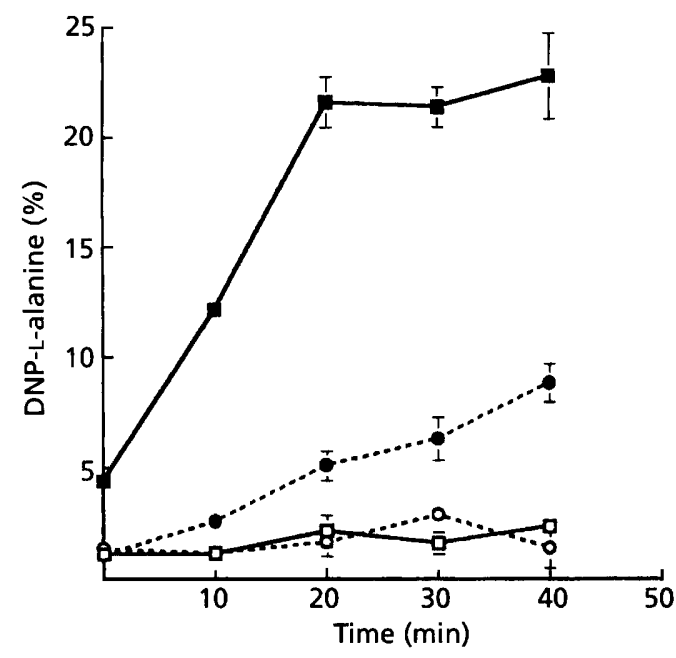

Fig. 9. $N$-acetylmuramoyl-L-alanine amidase assay with crude lysates of induced B. subtilis strains 168 and L4590::p517.5. Samples were treated as described in Methods. The amidase activity was measured as the release of free L-alanine $\mathrm{NH}_{2}$ groups which reacted with fluorodinitrobenzene to yield dinitrophenyl (DNP) alanine (Margot et al., 1991). The percentage of amidase-cleaved $\mathrm{N}$-acetylmuramoyl-L-alanine bonds was calculated as follows: $100 \times$ [DNP-L-alanine/(total DNP-L-alanine $+\mathrm{L}$-alanine)]. Non-induced (open symbols) and MMC induced (filled symbols) strains $168(\square, \square)$ and L4590::p517.5 (O, O).

residue, (ii) a charge-rich, hydrophilic C-terminus, and (iii) a basic isoelectric point. Protein XhlA of $10 \mathrm{kDa}$ presents a marked $\alpha$ helix-turn- $\alpha$ helix secondary structure. $x b l A$ and $x b l B$ differ from the structural gene of the $\lambda$ holin, since, unlike the latter, they do not have a dual MKM start motif. This motif, however, was shown to play a role in the modulation of the holin activity but not in its function as such. Therefore, it would seem that the combined action of these polypeptides could fulfil the function of a holin, i.e. release the endolysin by generating transmembrane lesions. This interpretation is strongly supported by observations of Lee et al. (1991), who showed that $x b l B$, named $x p a B$ in their study, can complement certain alkaline-phosphatase-deficient mutants of $E$. coli. Incidentally, orfL1 and $L 2$ of $B$. licheniformis (Fig. 10), similar to $x b l A$ and $x b l B$, also complemented certain alkaline phosphatase-deficient mutants of E. coli. Lee et al. (1991) suggested that complementation was due to altered membrane permeability. In view of our observations, we believe that Xpa-like proteins correspond to holins, and that Lee $e t$ al. (1991) have actually devised a relatively general test for the detection of such proteins.

The first of the four sequenced ORFs ( $x e p$, for PBSX exported protein) encodes the previously described PBSX protein P31. This protein, shown to be exported during phage development (Mauël \& Karamata, 1984), did not exhibit lytic activity (see above) and had no affinity for the cell wall (C. Mauël, unpublished). Its function remains unknown. However, the measured and the deduced molecular mass of P31 are identical, suggesting that this protein, devoid of the export signal, may also be extruded by a holin type mechanism, possibly that responsible for XlyA translocation.

Sequence similarity analysis revealed that the genetic
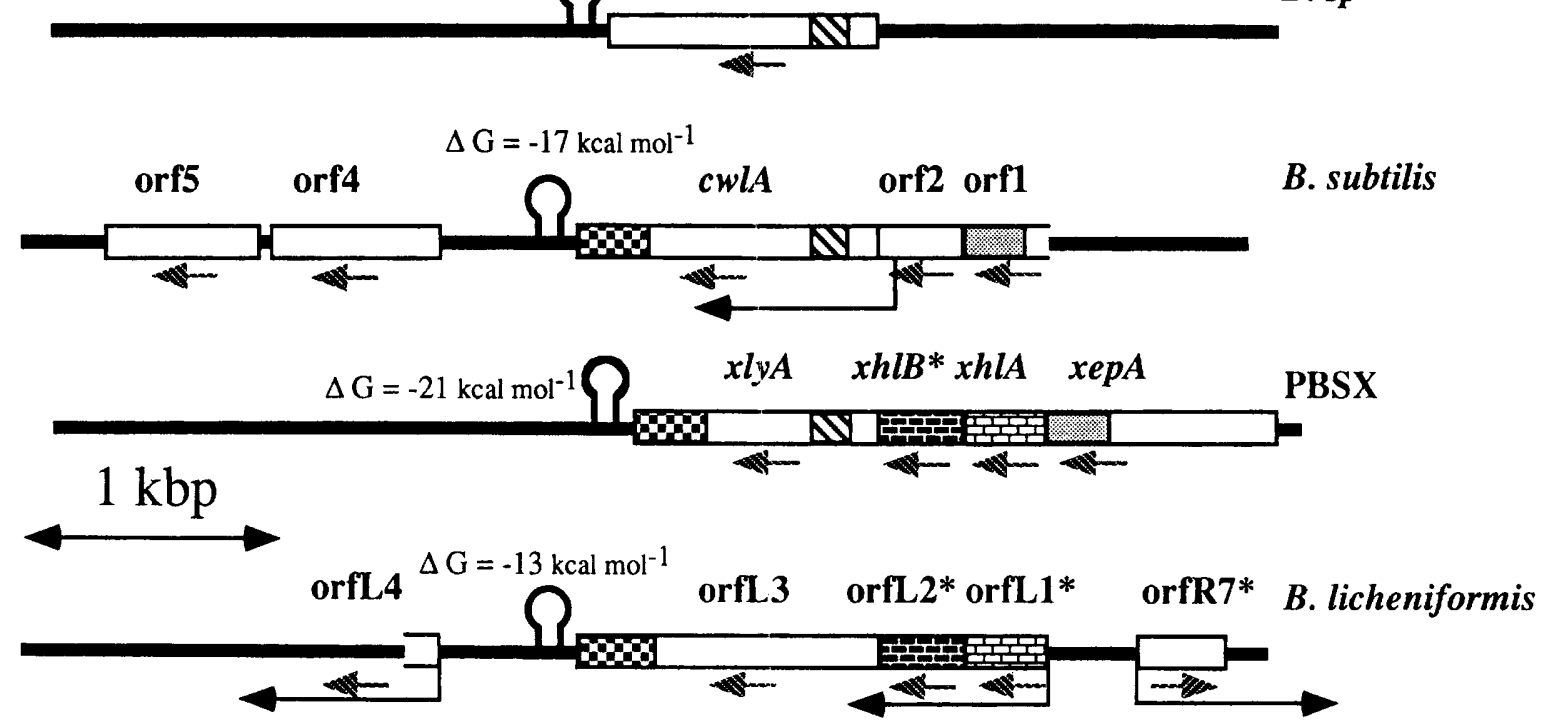

Fig. 10. Comparison of the relevant similar regions between PBSX and the genomes of $B$. subtilis, B. lichenformis and Bacillus sp. The ORFs described in different organisms, their putative terminator structure $(\Omega)$, sense of transcription $(-)$, and putative promoters $(\backsim)$ ) are specified. Symbols ( $\cdots, 0$, represent regions of similarity, while asterisks denote genes complementing the Pho- phenotype of $E$. coli phoA mutants. $1 \mathrm{kcal}=4 \cdot 184 \mathrm{~kJ}$. 
entity comprising $x y l A$ is present in more than one copy in the $B$. subtilis 168 genome. Indeed, the deduced amino acid sequence of $x l y A$ is $44 \%$ similar to that of $\mathrm{cwl} A$, an amidase-encoding gene located near aroD at about $226^{\circ}$ on the B. subtilis genetic map (Foster, 1991). Both genes are flanked by a strong terminator, while the region upstream of $c w / A$, so far sequenced, reveals a similar organization to that upstream of $x l y A$ (Fig. 10). $\mathrm{cwl} A$ is preceded by orf 2 , which, like $x h l B$, encodes a basic protein with two hydrophobic domains and a charged C-terminus, and which, in turn, is preceded by a partly sequenced gene transcribed in the same direction and similar to the $\mathrm{C}$ terminal end of $x e p A$. Preliminary Southern hybridization experiments (not presented) revealed that a $x l y A$-derived probe hybridized with three, possibly four, different loci, suggesting the presence of one or two copies of this gene, in addition to $x l y A$ and $c w l A$. Presence of multiple copies of endolysin genes has been reported in $B$. licheniformis (Oda et al., 1993) as well as in Streptococcus pneumoniae, where the close relationship between host and phage enzymes (Romero et al., 1990; Diaz et al., 1992) has provided strong support for the concept of the modular organization of proteins. In conclusion, these situations may be related to that of bacteriophage $\lambda$, several degenerate copies of which - rac, qsr' and qin prophages - were identified on the E. coli chromosome (Espion $e t$ al., 1983; Strathern \& Herskowitz, 1975).

Inspection of the data banks revealed that entities encompassing holins and $x l y A$-like genes are widespread among bacilli. A Bacillus sp. hydrolase and a B. licheniformis gene exhibit homologies to $x l y A$ and $c w l A$ (see above). It is, however, impossible to unambiguously attribute such entities to PBSX-like phages or to their degenerate copies. Indeed, if the unit described in B. licheniformis consists of a gene with some similarity to $x l y A$, flanked on one side by a terminator and on the other by two small ORFs, it is preceded by a divergently transcribed gene. Therefore, from the structural point of view, this entity forms a divergon and is unlikely to be part of a late phage transcription unit. The question remains as to whether such holin and endolysin-encoding units are of phage origin or whether the holin, and possibly endolysin genes, are chromosomal in origin and somehow brought under phage control.

The PBSX amidase presents an interesting feature regarding its translocation. On the one side, like the $\phi 29$ and $\lambda$ lytic enzymes, $x l y A$ is preceded by two genes encoding proteins which probably fulfil a holin function, while, on the other, it is endowed with a signal peptide, an unusual property for a bacteriophage endolysin (Steiner et al., 1993). Apparently, both export mechanisms are likely to be used. The $\mathrm{N}$-terminal amino acid sequence of XlyA (Foster, 1993) corresponds to that encoded by the signal peptide, implying that the uncleaved protein was exported, probably through a holin-like system. However, a protein similar to XlyA, the CwlA amidase which can be cloned and expressed in E. coli, is cleaved and possibly exported independently of the holin. Should this observation be confirmed for $x l y A$, which so far has been difficult to clone in $E$. coli, it would suggest a versatile system capable of using different strategies for lysing different hosts, i.e. Gram-positive and Gram-negative bacteria. This might reveal some ancestral phage with a wide host spectrum.

Finally, PX34, the other endolysin identified on cell-wallcontaining renaturing gels, possibly endowed with a muramidase activity (Ward et al., 1982), and shown to have an affinity for cell wall (C. Mauël, unpublished), does not seem to be encoded by the PBSX late operon. Although the possibility remains that the structural gene of PX34 is part of contiguous prophage regions which have not been cloned yet, it cannot be ruled out that this gene, controlled by the PBSX repressor is located elsewhere on the chromosome implying that the PBSX genome is scattered, i.e. that it forms a regulon.

\section{ACKNOWLEDGEMENTS}

Our thanks are due to Dr Heather Wood who kindly provided clones of the PBSX prophage, and to Dr Simon Foster for making available amino acid sequences prior to publication.

\section{REFERENCES}

Beliveau, C., Potvin, C., Trudel, J., Asselin, A. \& Bellemare, G. (1991). Cloning, sequencing, and expression in Escherichia coli of a Streptococcus faecalis autolysin. J Bacteriol 173, 5619-5623.

Burkholder, P. R. \& Giles, N. H. (1947). Induced biochemical mutants in Bacillus subtilis. Am J Bot 34, 345-348.

Buxton, R. S. (1976). Prophage mutation causing heat inductibility of defective Bacillus subtilis bacteriophage PBSX.J Virol 20, 22-28.

Buxton, R. S. (1980). Selection of Bacillus subtilis 168 mutants with deletion of the PBSX prophage. J Gen Virol 46, 427-437.

Calendard, R. (1988). The bacteriophages. In The Viruses, vol. 1, pp. 198, 304-305; vol. 2, pp. 265, 535. Edited by H. FraenkelConrat \& R. R. Wagner. New York: Plenum.

Chambers, S. P., Prior, S. E., Barstow, D. A. \& Minton, N. P. (1988). The pMTL nic- cloning vectors. I. Improved pUC polylinker region to facilitate the use of sonicated DNA for nucleotide sequencing. Gene 68, 139-149.

Chu, C. P., Kariyama, R., Daneo-Moore, L. \& Shockman, G. D. (1992). Cloning and sequence analysis of the muramidase-2 gene from Enterococcus hirae. J Bacteriol 174, 1619-1625.

Chung, C. T., Niemela, S. L. \& Miller, R. H. (1989). One-step preparation of competent Escherichia coli: transformation and storage of bacterial cells in the same solution. Proc Natl Acad Sci US A 86, 2172-2175.

Cutting, S. M. \& Vander Horn, P. B. (1990). Genetic analysis. In Molecular Biological Methods for Bacillus, pp. 27-74. Edited by C. R. Harwood \& S. M. Cutting. New York: John Wiley.

Dedonder, R. A., Lepesant, J. A., Lepesant-Keizlarova, J., Billault, A., Steinmetz, M. \& Kunst, F. (1977). Construction of a kit of reference strains for rapid genetic mapping in Bacillus subtilis 168. Appl Environ Microbiol 33, 989-993.

Del Sal, G., Manfioletti, G. \& Schneider, C. (1988). A one-tube plasmid DNA mini-preparation suitable for sequencing. Nucleic Acids Res 16, 9878.

Devereux, J., Haeberli, P. \& Smithies, O. (1984). A comprehensive set of sequence analysis programs for the VAX. Nucleic Acids Res 12, 387-395. 
Diaz, E., Lopez, R. \& Garcia, J. L. (1992). EJ-1, a temperate bacteriophage of Streptococcus pneumoniae with a myoviridae morphotype. J Bacteriol 174, 5516-5525.

Espion, D., Kaiser, K. \& Dambly-Chaudiere, C. (1983). A third defective lambdoid prophage of Escherichia coli $\mathrm{K} 12$ defined by the $\lambda$ derivative, iqin111. Mol Biol 170, 611-633.

Farmer, J. L. \& Rothman, F. (1965). Transformable thymine requiring mutant of Bacillus subtilis 168. J Bacteriol 127, 1427-14.42.

Feinberg, A. P. \& Vogelstein, B. (1983). A technique for racliolabelling DNA restriction endonuclease fragments to high specific activity. Anal Biochem 132, 6-13.

Foster, S. (1991). Cloning, expression, sequence analysis and biochemical characterization of an autolytic amidase of Bacillus subtilis 168 trpC2. J Gen Microbiol 137, 1987-1998.

Foster, S. (1992). Analysis of the autolysins of Bacillus subtilis 168 during vegetative growth and differentiation by using renaturing polyacrylamide gel electrophoresis. J Bacteriol 174, 464 470.

Foster, S. (1993). Analysis of Bacillus subtilis 168 prophageassociated lytic enzymes; identification and characterization of CWLA-related prophage proteins. J Gen Microbiol 139, 3177-31\&4.

Frischauf, A. M., Lehrach, H., Poustka, A. \& Murray, N. (1983). Lambda replacement vectors carrying polylinker sequences. $J$ Mol Biol 170, 827-842.

Garcia, E., Garcia, J. L., Garcia, P., Arraras, A., Sanchez-Puelles, J. M. \& Lopez, R. (1988). Molecular evolution of lytic enzymes of Streptococcus pneumoniae and its bacteriophages. Proc Natl Acad Sci US A 85, 914-918.

Garcia, P., Garcia, J. L., Garcia, E., Sanchez-Puelles, J. M. \& Lopez, R. (1990). Modular organization of the lytic enzymes of Streptococcus pneumoniae and its bacteriophages. Gene 86, 81-88.

Garvey, K. J., Saedi, M. S. \& Ito, J. (1986). Nucleotide sequence of Bacillus phage $\phi 29$ genes 14 and 15 : homology of gene 15 with other phage lysozymes. Nucleic Acids Res 14, 100001-10008.

Grossberger, D. (1987). Minipreps of DNA from bacteriophage lambda. Nucleic Acids Res 15, 6737.

Heery, D. M., Gannon, F. \& Powell, R. (1990). A simple method for: subcloning DNA fragments from gel slices. Trends Genet 6, 173.

von Heijne, G. (1986). A new method for predicting signal sequence: cleavage sites. Nucleic Acids Res 12, 4683-4690.

Huang, W. M. \& Marmur, J. (1970). Characterization of inducible bacteriophage in Bacillus licheniformis. J Virol 5, 237-246.

lonesco, H., Ryter, A. \& Schaeffer, P. (1964). Sur un bactériophage hébergé par la souche Marburg de Bacillus subtilis. Ann Inst Pasteur 107, 764-776.

Jaunin, P. (1987). Rôle des enzymes bactériolytiques du phage défectif PBSX dans le métabolisme de Penveloppe de Bacillus subtilis. MSc Diploma, University of Lausanne.

Kajie, S. I., Ideta, R., Yamato, I. \& Anraku, Y. (1991). Molecular cloning and DNA sequence of $d n i R$, a gene affecting anaerobic expression of the Escherichia coli hexaheme nitrite reductase. FEMS Microbiol Lett 83, 205-212.

Karamata, D. \& Gross, J. D. (1970). Isolation and genetic analysis of temperature-sensitive mutants of Bacillus subtilis 168. Mol \& Gen Genet 207, 73-81.

Kuroda, A. \& Sekiguchi, J. (1990). Cloning, sequencing and genetic mapping of a Bacillus subtilis cell wall hydrolase gene. J Gen Microbiol 136, 2209-2216.

Kuroda, A. \& Sekiguchi, J. (1991). Molecular cloning and sequencing of a major Bacillus subtilis autolysin gene. J Bacteriol 173, 7304-7312.
Lazarevic, V., Margot, P., Soldo, B. \& Karamata, D. (1992). Sequencing and analysis of the Bacillus subtilis lyt $\mathrm{R} A B C$ divergon: a regulatory unit encompassing the structural genes of the $\mathrm{N}$ acetylmuramoyl-L-alanine amidase and its modifier. J Gen Microbiot 138, 1949-1961.

Leclerc, D. \& Asselin, A. (1989). Detection of bacterial cell wall hydrolase after denaturing polyacrylamide gel electrophoresis. Can J Microbiol 35, 749-753.

Lee, J. K., Edwards, C. W. \& Hulett, F. M. (1991). Identification of four unique clones encoding $10 \mathrm{kDa}$ proteins from Bacillus that cause phenotypic complementation of a pho $A$ mutant strain of Escherichia coli. J Gen Microbiol 137, 667-677.

Longchamp. P. F. (1990). Etude de Porganisation génétique du bactériophage défectif PBSX de Bacillus subtilis par mutagenèse d' insertion. MSc Diploma, University of Lausanne.

Margot, P., Roten, C.-A. \& Karamata, D. (1991). Nacetylmuramoyl-L-alanine amidase assay based on specific radioactive labeling of muropeptide L-alanine: quantitation of the enzyme activity in the autolysin deficient Bacillus subtilis 168, faD strain. Anal Biochem 198, 15-18.

Mauël, C. (1984). Rôle des gènes DNA de Bacillus subtilis dans Pinduction et le développement du bactériophage défectif PBSX. PhD thesis, University of Lausanne.

Mauël, C. \& Karamata, D. (1984). Characterization of proteins induced by mitomycin $\mathrm{C}$ treatment of Bacillus subtilis. J Virol 49 , 806-812.

Noirot, P., Petit, M. A. \& Ehrlich, S. D. (1987). Plasmid replication stimulates DNA recombination in Bacillus subtilis. J Mol Biol 196 , 39-48.

Oda, Y., Nakayama, R., Kuroda, A. \& Sekiguchi, J. (1993). Molecular cloning, sequence analysis, and characterization of a new cell wall hydrolase, CwlL, of Bacillus licheniformis. Mol \& Gen Genet 241, 380-388.

Okamoto, K., Mudd, J. A., Mangan, J., Huang, W. M., Subbaiah, T. V. \& Marmur, J. (1968). Properties of the defective phage of Bacillus subtilis. J Mol Biol 34, 413-428.

Oultram, J. D., Peck, H., Brehm, J. K., Thompson, D., Swinfield, T. J. \& Minton, N. P. (1988). Introduction of genes for leucine biosynthesis from Clostridium pasteurianum into Clostridium acetobutylicum. Mol \& Gen Genet 214, 177-179.

Potvin, C., Leclerc, D., Tremblay, G., Asselin, A. \& Bellemare, G. (1988). Cloning, sequencing and expression of a Bacillus bacteriolytic enzyme in Escherichia coli. Mol \& Gen Genet 214, 241-248.

Reed, K. C. \& Mann, D. A. (1985). Rapid transfer of DNA from agarose gels to nylon membranes. Nucleic Acids Res 13, 7207-7221.

Romero, A., Lopez, R. \& Garcia, P. (1990). Sequence of the Streptococcus pneumoniae bacteriophage HB-3 amidase reveals high homology with the major host autolysin. J Bacteriol 172, 5064-5070.

Sanger, F., Nicklen, S. \& Coulson, A. R. (1977). DNA sequencing with chain-terminating inhibitors. Proc Natl Acad Sci USA 74, 5463-5467.

Seaman, E., Tarmy, E. \& Marmur, J. (1964). Inductible phages of Bacillus subtilis. Biochemistry 3, 607-612.

Shine, J. \& Dalgarno, L. (1974). The 3'-terminal sequence of Escherichia coli $16 \mathrm{~S}$ ribosomal RNA: complementary to nonsense triplets and ribosome binding sites. Proc Natl Acad Sci USA 71, 1342-1346.

Shuttleworth, H. L., Duggleby, C. J., Jones, S. A., Atkinson, T. \& Minton, N. P. (1987). Nucleotide sequence analysis of the gene for protein A from Staphylococcus aureus Cowan 1 (NCTC 8530) and its enhanced expression in Escherichia coli. Gene 58, 283-295. 
Siegel, E. C. \& Marmur, J. (1969). Temperature-sensitive induction of bacteriophage in Bacillus subtilis 168. J Virol 4, 610-618.

Southern, E. M. (1975). Detection of specific sequences among DNA fragments separated by gel electrophoresis. $J$ Mol Biol 98, 503-517.

Steensma, H. Y., Robertson, L. A. \& Van Elsa, J. D. (1978). The occurrence and taxonomic value of PBSX-like defective phages in the genus Bacillus. Antonie Leeunvenhoek 44, 353-366.

Steiner, M., Lubitz, W. \& Bläsi, U. (1993). The missing link in phage lysis of gram-positive bacteria : gene 14 of Bacillus subtilis phage $\phi 29$ encodes the functional homolog of Lambda $\mathrm{S}$ protein. $J$ Bacteriol 175, 1038-1042.

Strathern, A. \& Herskowitz, I. (1975). Defective prophage in Escherichia coli K12 strains. Virology 67, 136-143.

Studer, R. E. \& Karamata, D. (1988). Cell wall proteins in Bacillus subtilis. In Antibiotic Inbibition of Bacterial Cell Surface Assembly and Function, pp. 146-150. Edited by P. Actor. Washington, DC: American Society for Microbiology.

Thurm, P. \& Garro, A. J. (1975a). Bacteriophage-specific protein synthesis during induction of the defective Bacillus subtilis bacteriophage PBSX. J Virol 16, 179-183.

Thurm, P. \& Garro, A. J. (1975b). Isolation and characterization of prophage mutants of the defective Bacillus subtilis bacteriophage PBSX. J Virol 16, 184-191.
Tinoco, I., Borer, P. N., Dengler, B., Levine, M. D., Uhlenbeck, O. C., Crothers, D. M. \& Gralla, J. (1973). Improved estimation of secondary structure in ribonucleic acids. Nature New Biol 246, 40-41.

Tsutsumi, Y., Hirokawa, H. \& Shishido, K. (1990). A new defective phage containing a randomly selected 8 kilobase-pairs fragment of host chromosomal DNA inducible in a strain of Bacillus natto. FEMS Microbiol Lett 72, 41-46.

Ward, J. B., Curtis, C. A. M., Taylor, C. \& Buxton, R. S. (1982). Purification and characterization of two phage PBSX-induced lytic enzymes of Bacillus subtilis 168: an $N$-acetylmuramoyl-L-alanine amidase and an $N$-acetylmuramidase. $J$ Gen Microbiol 128, $1171-1178$

Wood, H. E., Dawson, M. T., Devine, K. M. \& McConnell, D. J. (1990a). Characterization of PBSX, a defective prophage of Bacillus subtilis. J Bacteriol 172, 2667-2674.

Wood, H. E., Devine, K. M. \& McConnell, D. J. (1990b). Characterization of a repressor gene $(x r e)$ and a temperature-sensitive allele from Bacillus subtilis prophage, PBSX. Gene 96, 83--88.

Young, R. (1992). Bacteriophage lysis: mechanism and regulation. Microbiol Rev 56, 430-480.

Received 23 November 1993; revised 11 February 1994; accepted 11 March 1994. 